\title{
The effects of 90-day feeding of D-psicose syrup in male Wistar rats
}

\author{
Tatsuhiro Matsuo ${ }^{1^{*}}$, Reika Ishii $^{1}$, Yoko Shirai $^{2}$ \\ ${ }^{1}$ Faculty of Agriculture, Kagawa University, Kagawa, Japan; *Corresponding author: matsuo@ag.kagawa-u.ac.jp \\ ${ }^{2}$ National Institute for Materials Science, Tsukuba, Japan.
}

Received 2 June 2011; revised 14 July 2011; accepted 30 July 2011.

\begin{abstract}
D-Psicose is a rare sugar present in small quantities in natural products. In a previous study, we showed that D-psicose suppresses increase in plasma glucose and reduces body fat accumulation in rats. Based on acute and chronic toxicity testing in rats, D-psicose is classified as an ordinary and safe substance. Recently, we developed a high D-psicose syrup (PS) made from high fructose corn syrup (HFCS) by the alkaline isomerization method. However, the safety of PS as a food additive has not been demonstrated. In this study, we investigated the effects of 90-day feeding of PS in male Wistar rats. The rats were fed diets containing 3\% D-psicose (control) or $4.3 \%$ PS for 90 days. The body weight gain and intra-abdominal adipose tissue weight did not differ between the control and PS group. The weights of the tissues did not differ between the two dietary groups. In clinical chemistry and hematological analyses, no differences were found between the control and PS groups. No gross pathological findings were evident at dietary doses of $4.3 \%$ PS. Therefore, the present study found no adverse effects of PS in rats fed a diet containing $4.3 \%$ PS for 90 days.
\end{abstract}

Keywords: D-Psicose; D-Psicose Syrup; 90-Day Feeding; Pathological Tests; Rat

\section{INTRODUCTION}

D-Psicose (D-ribo-2-hexulose), a C-3 epimer of Dfructose, is a "rare sugar" present in small quantities in commercial mixtures of D-glucose and D-fructose obtained by hydrolysis of sucrose or isomerization of Dglucose [1]. D-Psicose is also present in processed cane and beet molasses [2], and is found in wheat [3], Itea plants [4], and in the antibiotic psicofranine [5]. In the 2000s, D-psicose began to be made using an enzymatic method on a large scale, making it possible to conduct biochemical and nutritional studies [6]. Examining the effects of D-psicose on glucose and lipid metabolism, we found that D-psicose is a sweet monosaccharide that provides no energy to growing rats and leads to less intra-abdominal fat accumulation than D-glucose and Dfructose in rats $[7,8]$. In addition, we suggested previously that supplemental D-psicose can lower plasma glucose levels [9]. Toyoda et al. [10] suggested that Dpsicose can prevent postprandial hyperglycemia by improving the translocation of glucokinase from the nucleus to the cytoplasm in the liver of diabetic rats. Dpsicose is expected to have a beneficial effect in the control of blood glucose levels in type 2 diabetes.

Based on acute toxicity testing in rats, D-psicose is classified as an ordinary substance, with an oral $\mathrm{LD}_{50}$ value of $16 \mathrm{~g} / \mathrm{kg}$ in male Wistar rats [11]. D-psicose, which is naturally present in foods such as fruit juice and fruit cereal, is derived from D-fructose by the cooking process [2,12]. Oshima et al. [13] reported that in highsugar food products, heat processing had a marked effect on the production of D-psicose. In particular, con-fectionery products and seasoning sauces exhibited higher D-psicose content $(0.005-1.3 \mathrm{mg} / \mathrm{g})$ than other products [13]. As a result, most people ingest a limited amount of D-psicose on a daily basis. Furthermore, we examined the effects of sub-chronic (90 days) and long-term feeding (12 - 18 months) of D-psicose to rats prior to its utilization as a physiologically functional food $[14,15]$. We showed that 3\% D-psicose in the diet had no adverse effects in rats.

Recently, we developed a new product, high D-psicose syrup (85\% D-psicose) made from high fructose corn syrup (HFCS) by the alkaline isomerization method. D-Psicose syrup (PS) can be easily and cost-effectively produced compared to D-psicose. However, as PS includes small amounts of unknown ingredients (probably 
several monosaccharides), the safety of PS as a lowenergy sweetener or food additive is not clear.

In this study, to assess the safety of PS, the effects of 90-day feeding of PS was conducted in rats at a dietary dose of $4.3 \%$ PS (including 3\% D-psicose). The objective of this study was to determine whether PS can be safety used as a functional food similar to D-psicose.

\section{MATERIALS AND METHODS}

All procedures involving animals were approved by the Animal Care Committee of Kagawa University.

\subsection{Animals and Experimental Diets}

Twenty male Wistar rats (3 weeks old) were obtained from Japan SLC (Shizuoka, Japan). They were fed CE-2, a commercial rodent diet (CLEA, Tokyo, Japan) and water ad libitum until they were 4 weeks old. They were caged individually at $22^{\circ} \mathrm{C} \pm 2{ }^{\circ} \mathrm{C}$, with lights on from 08:00 to 20:00. The rats were randomly divided into two groups of 10 (control and PS groups). We adopted Dpsicose as a control for PS because the safety of D-psicose was confirmed by our previous studies in animals and humans [11,14-16]. The compositions of experimental diets are shown in Table 1. The compositions of PS were as follows: D-psicose, 70\%; water, 17\%; unknown ingredients, $13 \%$. The control and PS diets included 3\% D-psicose in CE-2, a commercial rodent chow (CLEA). The amount of test carbohydrates was determined with reference to previous studies concerning D-psicose [13] or sucralose, the $\mathrm{LD}_{50}$ of which is the same as that of D-psicose $[17,18]$. Each group of rats was given free access to food and water for 90 days. PS, which was made from HFCS by the alkaline isomerization method, and D-psicose, which was made enzymatically from D-fructose, were gifts from Rare Sugar Production Technical Research Laboratories, LLC (Kagawa, Japan). The HFCS used as a raw material for PS was supplied by Matsutani Chemical Industry, Co., Ltd. (Hyogo, Japan).

Table 1. Composition of experimental diets.

\begin{tabular}{ccc}
\hline Groups & Control & D-Psicose syrup \\
\hline Ingredients & \multicolumn{2}{c}{$\mathrm{g} / \mathrm{kg}$} \\
CE-2 & 95.7 & 95.7 \\
D-Psicose syrup & 0.0 & 4.3 \\
D-Psicose & 3.0 & 0.0 \\
Sucrose & 0.5 & 0.0 \\
Distilled water & 0.7 & 0.0 \\
Total & 1000.0 & 1000.0 \\
\hline
\end{tabular}

${ }^{*} 17 \%$ of water is included. D-Psicose includs $85 \%$ of solid content.

\subsection{Experimental Design}

After 90 days of feeding, rats in each group were fasted for $4.5 \mathrm{~h}$ beginning at 06:00, and then anesthetized by intraperitoneal administration of sodium pentobarbital. Blood was collected from the abdominal aorta for clinical hematological analysis and to obtain serum for chemical analysis. The rats were exsanguinated. The brain, heart, lungs, liver, pancreas, kidneys, adrenal glands, spleen, testes, intra-abdominal adipose tissues (epididymal, perirenal, and mesenteric), and muscle tissues (soleus, gastrocnemius, and plantarius) were rapidly removed and weighed. Parts of the liver, kidneys, and small intestine (about $5 \mathrm{~mm}$ of the end of the jejunum) were preserved in $10 \%$ neutral buffered formalin for histopathological examinations. The stomach, small intestine, large intestine, and cecum were also rapidly removed and weighed. In addition, the small and large intestine length, surface area, and cecal content weight were measured.

\subsection{Analysis}

The following hematological and clinical chemistry parameters were evaluated white blood cell count (WBC), red blood cell count (RBC), hemoglobin (Hb), hematocrit (Ht), mean corpuscular volume (MCV), mean corpuscular hemoglobin (MCH), mean corpuscular hemoglobin concentration (MCHC), platelet count (PLT), total protein (TP), ratio of albumin and globulin (A/G), albumin (ALBU), globulin (GLO), aspartate aminotransferase (AST), alanine aminotransferase (ALT), uric acid (UA), urea nitrogen (BUN), creatinine (CREA), calcium (Ca), iron (Fe), total cholesterol (CHO), triglyceride (TG), glucose (GLU), and free fatty acids (FFA). The hematological and chemical analyses were performed by Shikokuchuken Co., Ltd. (Kagawa, Japan). The histopathological examinations were performed by Shikoku Cytopathology Center Co., Ltd. (Kagawa, Japan). Fixed tissue samples from the liver, kidney, and small intestine were embedded in paraffin and cut into sections 5 - $6 \mu \mathrm{m}$ thick on a microtome. The tissue sections were stained with hematoxylin and eosin (HE) and examined by light microscopy. Next, the histopathological findings in each rat were subjectively quantified as follows:,$- 0 ; \pm, 1 ;+, 2 ;++, 3 ;+++, 4$.

\subsection{Statistical Analysis}

All values are expressed as the mean \pm SD. Statistical analysis of the differences between the control and PS groups was performed using Student's $t$-test. Statistical significance was set at $p<0.05$. All analyses were performed with a commercially available statistical software package (Excel Statistics 2008; SSRI, Co., Ltd., 
Tokyo, Japan).

\section{RESULTS}

\subsection{Body and Tissue Weights, Food Intake, and Digestive Tract Size}

The body and tissue weights, food intake, and digestive tract size in rats fed the two experimental diets for

Table 2. Body weight, food intake, tissue weights and digestive tract size.

\begin{tabular}{|c|c|c|c|}
\hline Groups & & Control & D-Psicose syrup \\
\hline Initial weight & (g) & $60 \pm 6$ & $59 \pm 5$ \\
\hline Final weight & (g) & $334 \pm 19$ & $348 \pm 25$ \\
\hline Weight gain & (g) & $274 \pm 16$ & $289 \pm 22$ \\
\hline Food intake & (g/day) & $19.3 \pm 1.1$ & $19.5 \pm 0.8$ \\
\hline \multicolumn{4}{|l|}{ Tissue weights } \\
\hline Brain & (g) & $1.39 \pm 0.33$ & $1.71 \pm 0.25$ \\
\hline Heart & (g) & $0.78 \pm 0.05$ & $0.82 \pm 0.06$ \\
\hline Lungs & (g) & $0.93 \pm 0.07$ & $1.00 \pm 0.10$ \\
\hline Liver & (g) & $10.4 \pm 0.90$ & $10.4 \pm 1.34$ \\
\hline Pancreas & (g) & $0.51 \pm 0.07$ & $0.55 \pm 0.08$ \\
\hline Kidneys & (g) & $2.27 \pm 0.18$ & $2.36 \pm 0.20$ \\
\hline Adrenals & (g) & $0.05 \pm 0.01$ & $0.05 \pm 0.01$ \\
\hline Spleen & (g) & $0.72 \pm 0.08$ & $0.73 \pm 0.06$ \\
\hline Testicles & (g) & $3.10 \pm 0.14$ & $3.11 \pm 0.11$ \\
\hline Intra-adipose tissues $^{1}$ & (g) & $21.5 \pm 2.79$ & $20.8 \pm 4.02$ \\
\hline Muscle tissues $^{2}$ & (g) & $3.77 \pm 0.18$ & $3.91 \pm 0.23$ \\
\hline \multicolumn{4}{|l|}{ Digestive tracts } \\
\hline Stomach weight & (g) & $1.98 \pm 0.49$ & $2.62 \pm 0.49$ \\
\hline Small intestine weight & (g) & $5.28 \pm 0.48$ & $5.66 \pm 0.52$ \\
\hline Small intestine length & (m) & $1.06 \pm 0.04$ & $1.10 \pm 0.05$ \\
\hline Large intestine weight & (g) & $1.09 \pm 0.11$ & $1.09 \pm 0.18$ \\
\hline Large intestine length & $\left(\times 10^{-2} \cdot \mathrm{m}\right)$ & $16.9 \pm 2.16$ & $18.3 \pm 2.36$ \\
\hline Cecal weight & (g) & $0.74 \pm 0.15$ & $0.77 \pm 0.05$ \\
\hline Cecal surface area & $\left(\times 10^{3} \cdot \mathrm{mm}^{2}\right)$ & $3.76 \pm 0.54$ & $4.06 \pm 0.40$ \\
\hline
\end{tabular}

Values are means \pm SD for 10 rats. ${ }^{1}$ Total weight of epididymal, perirenal and mesenteric adipose tissues. ${ }^{2}$ Total weight of soleus, gastrocnemius and plantaris muscles.
Table 3. Blood hematological and serum chemical values.

\begin{tabular}{|c|c|c|c|}
\hline Group & & Control & D-Psicose syrup \\
\hline \multicolumn{4}{|l|}{ Blood } \\
\hline WBC & $\left(\times 10^{2} / \mu \mathrm{l}\right)$ & $30.2 \pm 3.0$ & $29.6 \pm 4.6$ \\
\hline $\mathrm{RBC}$ & $\left(\times 10^{4} / \mu \mathrm{l}\right)$ & $892 \pm 24$ & $892 \pm 23$ \\
\hline $\mathrm{Hb}$ & $(\mathrm{g} / 100 \mathrm{ml})$ & $14.4 \pm 0.4$ & $14.7 \pm 0.5$ \\
\hline $\mathrm{Ht}$ & (\%) & $46.3 \pm 1.4$ & $46.4 \pm 1.4$ \\
\hline MCV & (fl) & $52.0 \pm 1.0$ & $52.0 \pm 1.0$ \\
\hline $\mathrm{MCH}$ & (pg) & $16.2 \pm 0.2$ & $16.4 \pm 0.3$ \\
\hline $\mathrm{MCHC}$ & (\%) & $31.2 \pm 0.6$ & $31.6 \pm 0.5$ \\
\hline PLT & $\left(\times 10^{4} / \mu \mathrm{l}\right)$ & $56.6 \pm 8.5$ & $56.1 \pm 2.0$ \\
\hline \multicolumn{4}{|l|}{ Serum } \\
\hline $\mathrm{TP}$ & (g/100 ml) & $6.23 \pm 0.18$ & $6.15 \pm 0.20$ \\
\hline $\mathrm{A} / \mathrm{G}$ & & $3.17 \pm 0.49$ & $3.04 \pm 0.34$ \\
\hline ALBU & $(\mathrm{g} / 100 \mathrm{ml})$ & $4.72 \pm 0.25$ & $4.62 \pm 0.21$ \\
\hline GLO & $(\mathrm{g} / 100 \mathrm{ml})$ & $1.51 \pm 0.15$ & $1.53 \pm 0.13$ \\
\hline TBIL & $(\mathrm{mg} / 100 \mathrm{ml})$ & $0.20 \pm 0.00$ & $0.20 \pm 0.00$ \\
\hline DBIL & $(\mathrm{mg} / 100 \mathrm{ml})$ & $0.10 \pm 0.00$ & $0.10 \pm 0.00$ \\
\hline IBIL & $(\mathrm{mg} / 100 \mathrm{ml})$ & $0.10 \pm 0.00$ & $0.10 \pm 0.00$ \\
\hline AST & (IU/I) & $230 \pm 32$ & $172 \pm 92$ \\
\hline ALT & (IU/I) & $76.1 \pm 19.4$ & $87.9 \pm 48.2$ \\
\hline UA & $(\mathrm{mg} / 100 \mathrm{ml})$ & $1.22 \pm 0.26$ & $1.14 \pm 0.36$ \\
\hline BUN & $(\mathrm{mg} / 100 \mathrm{ml})$ & $20.8 \pm 1.7$ & $22.2 \pm 2.1$ \\
\hline CREA & $(\mathrm{mg} / 100 \mathrm{ml})$ & $0.27 \pm 0.03$ & $0.30 \pm 0.05$ \\
\hline $\mathrm{Ca}$ & $(\mathrm{mg} / 100 \mathrm{ml})$ & $10.2 \pm 0.2$ & $10.4 \pm 0.3$ \\
\hline $\mathrm{Fe}$ & $(\mu \mathrm{g} / 100 \mathrm{ml})$ & $110 \pm 25$ & $111 \pm 13$ \\
\hline $\mathrm{CHO}$ & $(\mathrm{mg} / 100 \mathrm{ml})$ & $70.1 \pm 10.0$ & $68.8 \pm 12.5$ \\
\hline TG & $(\mathrm{mg} / 100 \mathrm{ml})$ & $79.6 \pm 36.1$ & $69.0 \pm 32.4$ \\
\hline GLU & $(\mathrm{mg} / 100 \mathrm{ml})$ & $156 \pm 14$ & $167 \pm 14$ \\
\hline FFA & $(\mathrm{mEq} / 100 \mathrm{ml})$ & $0.87 \pm 0.24$ & $0.70 \pm 0.11$ \\
\hline
\end{tabular}

Values are means \pm SD for 10 rats.

90 days are presented in Table 2. The final body weight, weight gain, and food intake did not differ between the control and PS groups. The mean stomach and cecal content weights were significantly higher in the PS group than in the control group, but no differences were observed in any other tissues.

\subsection{Serum Chemical and Blood Hematological Values}

No differences were observed in any chemical or hematological values between the control and PS groups (Table 3). These values remained within the normal ranges, indicating that there was no overt PS toxicity.

\subsection{Histopathological Examination}

The histopathological observations of the liver, kidney, 
and small intestine are presented in Table 4. Age-related naturally-occurring lesions were observed in the tissues, but no abnormalities due to the ingestion of PS were observed. The histopathological examination showed no differences in the total damage in the liver, kidneys, and small intestine between the control and PS groups.

\section{DISCUSSION}

In the present 90-day feeding study of PS at a dose of $4.3 \%$ in male Wistar rats, no mortality occurred, and systemic toxicity was not evident. We have examined the effects of acute [11], sub-chronic (90 days) [15], and long-term feeding (12 - 18 months) [14] of D-psicose to rats prior to its utilization as a physiologically functional food. We concluded that a small amount of D-psicose in the diet had no adverse effects in rats. In the present study, we focused on the safety of impurities (0.5\% unknown ingredients) of the PS rather than safety of the PS itself. Therefore, the control diet included $0.5 \%$ sucrose for comparison with $0.5 \%$ impurities in the PS diet.

Generally, small amounts of impurities are included in natural products and processed foods [19]. For example, royal jelly has been widely used as a dietary supplement and in cosmetics in many countries [20]. With regard to chemical composition, royal jelly was reported to consist mainly of proteins, sugars, lipids, vitamins, and many unknown ingredients [21,22]. The main active ingredients of royal jelly are not clear, but royal jelly is recognized as a safe food or supplement [23]. On the other hand, HFCS also contains about 6\% unknown ingredients [24]. However, HFCS has already been generally used in many developed countries [25]. PS includes un-

Table 4. Histopathological observations of liver, kidney and small intestine ${ }^{1}$.

\begin{tabular}{|c|c|c|c|}
\hline Groups & & Control & D-Psicose syrup \\
\hline Ogans & Findings & & \\
\hline \multirow[t]{6}{*}{ Liver } & Bile duct proliferation & $0.0 \pm 0.0$ & $0.0 \pm 0.0$ \\
\hline & Necrosis & $0.2 \pm 0.4$ & $1.9 \pm 1.0$ \\
\hline & Microgranuloma & $0.4 \pm 0.5$ & $1.2 \pm 1.0$ \\
\hline & Lipid deposition & $0.0 \pm 0.0$ & $0.0 \pm 0.0$ \\
\hline & Fatty change & $0.0 \pm 0.0$ & $0.0 \pm 0.0$ \\
\hline & Total score of damage & $0.6 \pm 0.7$ & $3.1 \pm 1.4$ \\
\hline \multirow[t]{8}{*}{ Kidney } & Basophilic change in the tubule & $1.0 \pm 1.3$ & $1.2 \pm 1.2$ \\
\hline & Hyaline cast in the tubule & $0.8 \pm 0.8$ & $1.0 \pm 0.8$ \\
\hline & Brown pigment deposition in the tubule & $0.0 \pm 0.0$ & $0.0 \pm 0.0$ \\
\hline & Atrophy of the glomerulus & $0.0 \pm 0.0$ & $0.0 \pm 0.0$ \\
\hline & Hyalinization in the glomerulus & $0.0 \pm 0.0$ & $0.0 \pm 0.0$ \\
\hline & Thickening of Bowman's capsule basement membrane & $0.0 \pm 0.0$ & $0.0 \pm 0.0$ \\
\hline & Lymphocyte infiltration in the interstitium & $0.2 \pm 0.4$ & $0.4 \pm 0.5$ \\
\hline & Total score of damage & $1.5 \pm 1.3$ & $2.0 \pm 1.5$ \\
\hline \multirow[t]{5}{*}{ Small intestine } & Villous damage & $0.4 \pm 0.7$ & $1.2 \pm 1.0$ \\
\hline & Crypt damage & $0.1 \pm 0.3$ & $0.4 \pm 0.5$ \\
\hline & Cellular infiltration & $0.9 \pm 0.6$ & $0.8 \pm 0.9$ \\
\hline & Goblet cell depletion & $0.1 \pm 0.3$ & $0.5 \pm 0.9$ \\
\hline & Total score of damage & $1.5 \pm 1.7$ & $2.9 \pm 2.2$ \\
\hline
\end{tabular}

Values are means \pm SD for 10 rats. ${ }^{1}$ Quantify the findings level of damage in each rats:,$- 0 ; \pm, 1 ;+, 2 ;++, 3 ;+++, 4$. 
known impurities, but it is likely to be a safe food product. The PS was made from HFCS by the alkaline isomerization method. The alkaline isomerization method is used widely, resulted in production of many sugar products, such as cyclodextrin, maltitol, and erythritol [26].

D-Psicose can be produced by the enzymatic method on a large scale, making it possible to conduct biochemical and nutritional studies [6]. We found that Dpsicose is a sweet monosaccharide that provides no energy and leads to less body fat accumulation than Dglucose and D-fructose in rats $[7,8]$. In addition, we have suggested that supplemental D-psicose can lower plasma glucose levels [9]. D-Psicose is expected to have a beneficial effect in the control of blood glucose levels in type 2 diabetes. However, D-psicose is more expensive than other substitute sugars. However, PS can be produced more easily and cost-effectively than D-psicose. PS may be effective for the prevention obese or type 2 diabetes as functional foods.

In conclusion, the present study evaluated the effects of 90-day 4.3\% PS administration to rats, and there were no gross pathological findings. The hematological and chemical values were not suggestive of any overt PS toxicity. Overall, no adverse effects were seen at this low dose level of PS in the diet.

\section{ACKNOWLEDGEMENTS}

We would like to thank Dr. Koji Kondo, Rare Sugar Production Technical Research Laboratories, LLC (Kagawa, Japan) for donating D-psicose. This work was supported by the Regional Innovation Creation R\&D Programs, Ministry of Economy, Trade and Industry, Japan.

\section{REFERENCES}

[1] Cree, G.M. and Perlin, A.S. (1968) O-Isopropylidene derivatives of D-allulose (D-psicose) and D-erythrohexopyranose-2,3-diulose. Canadian Journal of Biochemistry, 4, 765-770.

[2] Binkley, W.W. (1963) The fate of cane juice simple sugars during molasses formation. IV. Probable conversion of D-fructose to D-psicose. International Sugar Journal, 65, 105-106.

[3] Miller, B.S. and Swain, T. (1965) Chromatographic analyses of the free amino acids, organic acids and sugars in wheat plant extracts. Journal of the Science of Food and Agricalture, 11, 344-348. doi:10.1002/jsfa.2740110609

[4] Hough, L. and Stacey, B.E. (1966) Variation in the allitol content of Itea plants during photosynthesis. Phytochemistry, 5, 171-175. doi:10.1016/S0031-9422(00)85095-5

[5] Eble, T.E., Hoeksema, H., Boyack, G.A. and Savage, G.M. (1959) Psicofuranine I. Discovery, isolation, and properties. Antibiotics and Chemotherapy, 9, 419-420.

[6] Granstrom, T.B., Takata, G., Tokuda, M. and Izumori, K. (2004) Izumoring: A novel and complete strategy for bioproduction of rare sugars. Journal of Bioscience and Bioengineering, 97, 89-94.

[7] Matsuo, T., Suzuki, H., Hashiguchi, M. and Izumori, K. (2002) D-Psicose is a rare sugar that provides no energy to growing rats. Journal of Nutritional Science and Vitaminology, 48, 77-80.

[8] Matsuo, T., Baba, Y., Hashiguchi, M., Takeshita, K., Izumori, K. and Suzuki, H. (2001) Less body fat accumulation with D-psicose diet versus D-fructose diet. Journal of Clinical Biochemistry and Nutrition, 30, 55-65.

[9] Matsuo, T. and Izumori, K. (2006) Effects of dietary D-psicose on diurnal variation in plasma glucose and insulin concentrations of rats. Bioscience, Biotechnology and Biochemistry, 70, 2081-2085. doi:10.1271/bbb.60036

[10] Toyoda, Y., Mori, S., Umemura, N., Futamura, Y., Inoue, H., Hata, T., Miwa, I., Mura,o K., Nishiyama, A. and Tokuda, M. (2010) Suppression of blood glucose levels by $\mathrm{D}$-psicose in glucose tolerance test in diabetic rats. Japanese Pharmacology and Therapeutics, 38, 261-269.

[11] Matsuo, T., Tanaka, T., Hashiguchi, M., Izumori, K. and Suzuki, H. (2002) Effects of oral acute administration and subchronic feeding of several levels of D-psicose in rats. Journal of Nutritional Science and Vitaminology, 48, 512-516.

[12] Oshima, H., Kimura, I. and Izumori, K. (2006) Synthesis and structure analysis of novel disaccharides containing D-psicose produced by endo- $1,4-\beta$-d-xylanase from Aspergillus sojae. Journal of Bioscience and Bioengineering, 101, 280-283. doi:10.1263/jbb.101.280

[13] Oshima, H., Kimura, I. and Izumori, K. (2006) Psicose contents in various food products and its origin. Food Science and Technology Research, 12, 137-143. doi:10.3136/fstr.12.137

[14] Yagi, K. and Matsuo, T. (2009) The study on long-term toxicity of D-psicose in rats. Journal of Clinical Biochemistry and Nutrition, 45, 271-277. doi:10.3164/jcbn.08-191

[15] Ishii, R., Shirai, Y. and Matsuo, T. (2011) The 90-day oral toxicity of D-psicose in male Wistar rats. Journal of Clinical Biochemistry and Nutrition, in press.

[16] Iida, T., Kishimoto, Y., Yoshikawa, Y., Okuma, K., Yagi, K., Matsuo, T. and Izumori, K. (2007) Estimation of maximum non-effect level of D-psicose in causing diarrhea in human subjects. Journal of Japanese Council for Advanced Food Ingredients Research, 10, 10-15.

[17] Goldsmith, L.A. (2000) Acute and subchronic toxicity of sucralose. Food Chemical Toxicology, 38, S53-S69. doi:10.1016/S0278-6915(00)00028-4

[18] Mann, S.W., Yuschak, M.M., Amyes, S.J.G., Aughton, P. and Finn, J.P. (2000) A combined chronic toxicity/ carcinogenic study of sucralose in Spragure-Dawley rats. Food Chemical Toxicology, 38, S71-S89. doi:10.1016/S0278-6915(00)00029-6

[19] Tidgewell, K., Clark, B.R. and Gerwick, W.H. (2010) The natural products chemistry of cyanobacteria. Comprehensive Natural Products II, 2, 141-181.

[20] Haydak, M.H. (1970) Honey bee nutrition. Annual Review of Entomology, 15, 143-156. doi:10.1146/annurev.en.15.010170.001043

[21] Takenaka, T. (1982) Chemical composition of royal jelly. 
Honeybee Sciences, 3, 69-74.

[22] Shinoda, M., Nakajin, S. Oikawa, T., Sato, K., Kamogawa, A. and Akiyama, Y. (1978) Biochemical studies on vasodilative factor in royal jelly. Yakugaku Zasshi, 98, 139-145.

[23] Kamakura, M., Maebuchi, M., Ozasa, S., Komori, M., Ogawa, T., Sakaki, T. and Moriya, T. (2005) Influence of royal Jelly on mouse hepatic gene expression and safety assessment with a DNA microarray. Journal of Nutritional Science and Vitaminology, 51, 148-155.

[24] Ruiz-Matute, A.I., Weiss, M., Sammatoro, D., Finely, J. and Sanz, M.L. (2010) Carbohydrate composition of high-fructose corn syrups (HFCS) used for bee feeding: Effect on honey composition. Journal of Agricultural and Food Chemistry, 58, 7317-7322. doi:10.1021/jf100758x

[25] Tappy, L., Kim, A.L., Tran, C. and Paquot, N. (2010) Fructose and metabolic diseases: New findings, new questions. Nutriton, 26, 1044-1049. doi:10.1016/j.nut.2010.02.014

[26] Moon, H.J., Jeya, M., Kim, I.W. and Lee, J.K. (2010) Biotechnological production of erythritol and its applications. Applied Microbiology and Biotechnology, 86, 1017-1025. doi:10.1007/s00253-010-2496-4 